Columbia Law School

Scholarship Archive

\title{
Constitutional War Powers in World War I: Charles Evans Hughes and the Power to Wage War Successfully
}

Matthew C. Waxman

Columbia Law School, mwaxman@law.columbia.edu

Follow this and additional works at: https://scholarship.law.columbia.edu/faculty_scholarship

Part of the Constitutional Law Commons, Military, War, and Peace Commons, and the Public Law and Legal Theory Commons

\section{Recommended Citation}

Matthew C. Waxman, Constitutional War Powers in World War I: Charles Evans Hughes and the Power to Wage War Successfully, 44 J. SUP. CT. HIST. 267 (2020).

Available at: https://scholarship.law.columbia.edu/faculty_scholarship/2670

This Article is brought to you for free and open access by the Faculty Publications at Scholarship Archive. It has been accepted for inclusion in Faculty Scholarship by an authorized administrator of Scholarship Archive. For more information, please contact scholarshiparchive@law.columbia.edu. 


\title{
Constitutional War Powers in World War I: Charles Evans Hughes and the Power to Wage War Successfully
}

\author{
MATTHEW C. WAXMAN
}

On September 5, 1917, at the height of American participation in the Great War, Charles Evans Hughes famously argued that "the power to wage war is the power to wage war successfully." This moment and those words were a collision between the onset of "total war," Lochner-era jurisprudence, and cautious Progressive-era administrative development. This article tells the story of Hughes's statement-including what he meant at the time and how he wrestled with some difficult questions that flowed from it. The article then concludes with some reasons why the story remains important today. ${ }^{1}$

\section{Hughes and the Fighting Constitution}

Hughes's "war powers axiom"- that the power to wage war is the power to wage war successfully - has been widely cited and quoted for the past century in court decisions and briefs. It is often used in executive branch opinions about war powers, including recent ones concerning wars against terrorist organizations. It frequently appears in legal scholarship about war powers. But when Hughes uttered those words that day, he was not doing so as a Supreme Court Justice - or in his other public roles, such as Secretary of State. He was speaking as a private member of the bar.

There is some irony that Hughes's voice would reverberate so influentially in war powers jurisprudence, given that he never ruled on a major war powers case as a judge. He served first on the Supreme Court from 1910 until 1916, when he stepped down to run for President as the Republican candidate against incumbent Democrat Woodrow Wilson, whose supporters stressed that he kept us out of the Great War. Hughes then served again, this time as Chief Justice, from 1930 to 1941 . Both of these happened to be relatively peaceful, dry spells for significant war powers cases, and in both instances, 
Hughes left the Court less than a year before the United States declared war.

In September 1917, when Hughes gave his most detailed analysis of constitutional war powers, he did so in a private capacity, not as a government official of any kind, in a speech to the annual meeting of the American Bar Association titled "War Powers Under the Constitution." Hughes defended expansive government powers invoked by Wilson and the Democrat-controlled Congress to wage modern, industrial-age and industrial-scale warfare.

By way of context, this was five months after the United States declared war on the side of the Allies against the Central Powers - a war that had already been destroying Europe for three years. ${ }^{3}$ During those months, the United States had built from near scratch a massive army unlike any previous American force. In doing so, the federal government had assumed unprecedented powers over American society. When President Wilson had requested a war declaration from Congress, he pledged not only to defend the United States from immediate aggression but also to prevent the recurrence of war and to make the world safe for democracy. These aims are especially important later in the story.

It is hard to imagine today a speech by any modern figure about major constitutional issues that would carry the weight of Hughes' words. The New York Times covered his American Bar Association speech on the front page, beneath the headline: "War Power Ample, Hughes Declares: He Tells Bar Association There Is Full Warrant for All that We Are Doing." 4 Many other major newspapers across the country covered or even distributed the remarks. For example, the St. Louis Post-Dispatch reprinted the entire speech in its Sunday editorial section later that week. ${ }^{5}$ It did not hurt that, in the later words of Justice Robert H. Jackson, Hughes "look[ed] like God and talk[ed] like God." Indeed, Hughes carried personal authority and credibility on constitutional issues to an extent that would be hard for anyone-especially in a private capacity - to match today.

So what were the issues Hughes was concerned with in this speech about "War Powers Under the Constitution"? Today's biggest constitutional war powers controversies tend to focus on the President, especially the question of whether the chief executive has the power to launch a military action or the scope of his exclusive powers over how military operations are carried out. But in 1917, there was no serious doubt that, in those circumstances, only Congress could take the nation formally into the Great War. In any event, Wilson sought and received Congress's war declaration in April of that year, as well as very broad delegations of power for all the other actions he took. At that time, the most contentious and consequential war powers questions were less about the President than about the scope of Congress's powers in wartime.

When Hughes proclaimed that "the power to wage war is the power to wage war successfully," he was making a detailed Article I argument about legislative power, namely, that by virtue of the Necessary and Proper Clause, Congress's powers expanded during war as necessary to provide the means needed for victory. If required by wartime exigency, Article I powers were to be read more expansively than during peacetime. Meanwhile, restrictions on those powers were to be loosened. This included loosening the principle of nondelegation, the idea that Congress could not transfer its policy-making function to the President. Hughes also envisioned a loosening of basic rights in wartime. Again, this was the Lochner era, so the most significant rights at that time were economic rights, such as freedom of contract.

Hughes described in his research notes these flexible, elastic wartime features as part of the "Genius of our institutions." ${ }^{6}$ He by no stretch invented the core idea that constitutional powers must match unpredictable and 
evolving security needs; he credits Alexander Hamilton for laying the idea's foundation in The Federalist, for example, and especially Federalist essay numbers 23 and 26. In those essays, Hamilton wrote about the core power of the government to protect the Union and the dangers of imposing immovable limits on its ability to do so. Hughes also credits President Lincoln for putting these ideas into action during the Civil War, a conflict that also required new levels of national mobilization and that generated many legal precursors to the specific powers Hughes discusses. But Hughes both expanded on the theory and lent special political and intellectual credibility to this understanding at a time of simultaneous upheaval in constitutional law and in military technology and strategy.

Over the past century since Hughes spoke, this basic view- that the Constitution bends to meet wartime needs - has been accepted by all three branches of government. At the time, however, he was pushing against two other powerful schools of thought in American constitutional thinking.

One of those contrary schools viewed war powers as "extra-constitutional": The Constitution did not have to accommodate wartime needs because its requirements would naturally be suspended in wartime. Hughes, by contrast, lodged all necessary war powers firmly within the Constitution.

Another school viewed congressional powers as fixed in both war and peace: The Constitution already built in all the express powers needed to wage war effectively, and the dangers of interpreting implied powers fluidly were too great to allow. Rejecting this rigid view, Hughes saw war powers as evolving, because warfare itself evolved. As he said in concluding his 1917 War Powers speech:

It has been said that the Constitution marches. That is, there are constantly new applications of unchanged powers, and it is ascer- tained in novel and complex situations, the old grants contain, in their general words and true significance, needed and adequate authority. So, also, we have a fighting constitution....

In the end, Hughes's view won out. In World War I, our "fighting Constitution" was marching at a very fast clip. No other single document better shows it.

\section{War Powers Controversies of 1917}

So what, then, were the specific controversies that Hughes had in mind in September 1917? Why did he feel the need to offer such a strong constitutional defense of the U.S. government's wartime actions?

In constitutional law discussions today, World War I is mostly remembered for free-speech restrictions. Most notably, after Congress passed the Espionage Act of 1917 and the Sedition Act of 1918, the Wilson Administration aggressively prosecuted hundreds of cases against publishers and dissenters for allegedly interfering with the war effort. Hughes does not say a word in his 1917 war powers speech about the Espionage Act, even though it had been passed several months earlier after considerable debate. He does not say anything about free expression at all, in fact, on which there was little judicial precedent at the time.

Instead, the two big issues that Hughes addresses - the ones at which his "power to wage war successfully" axiom aimedwere (1) the national draft and (2) extensive economic regulation. These were radical expansions of federal government authority based on Congress's war powers.

Note that these particular radical expansions - a national draft and extensive economic regulation - were actions taken on the home front. Controversial war powers were not about actions "over there"; they were about actions over here. They were domestic national powers deemed necessary 
to waging modern combat thousands of miles away-necessary because twentieth-century warfare looked nothing like the Framers could have imagined. These are also policies that are now constitutionally uncontroversial even in peacetime, following the New Dealera expansion of Congress's power over the domestic economy and following early Cold War experiences in maintaining permanently high levels of military readiness.

As to the draft, when the United States entered the war in April 1917-a war that had been devouring European soldiers at an unprecedented pace - the nation had only a few hundred thousand troops, mostly on the Mexican border. The political leadership knew that only a national draft, and more specifically a "selective service" system, could efficiently and rapidly grow that force by an order of magnitude while also keeping workers in critical industries in their jobs on the home front.

The draft was an emotional issue for Hughes. In the six weeks leading up to the speech, he had spent a lot of his time as chairman of the New York City Draft Appeals Board, reviewing petitions for draft exemptions submitted by city draftees. By the time Hughes spoke, the board was deciding hundreds of cases a day. Aware that he was sending young men to risk their lives overseas, Hughes insisted on personally signing each appellant's papers. ${ }^{7}$ The day before his war powers speech, he stood alongside former President Teddy Roosevelt and others in front of the New York Public Library to watch recently drafted soldiers march up Fifth Avenue. ${ }^{8}$ Many of those on parade likely had only weeks earlier received rejection letters bearing Hughes's signature to their draft appeals.

Doctrinally, the constitutionality of a draft might seem like a pretty easy question, given that Article I gives Congress an unqualified power to "raise and support armies," but throughout American history to that point there had been significant doubt whether the federal government could conscript soldiers and additional doubt about whether those conscripted soldiers could be sent abroad. Hughes, therefore, devoted a lot of his speech to this issue, and his notes contained vast research on it.

The strongest constitutional objection to a national draft was not, as one might guess, one based on individual rights. It was a structural argument about federalism. Involuntary conscription, ran the argument, was an integral aspect of traditional state militia powers protected by the Constitution's Militia Clauses. Those clauses give states the power to keep and train well-regulated militias (historically made up heavily of local conscripts) that could be called into service by Congress for limited purposes. To allow the federal government to conscript able-bodied men directly could, in effect, nullify these state prerogatives and protections. This constitutional objection had carried powerful weight when Secretary of War James Monroe unsuccessfully recommended a federal draft during the War of 1812 and during the Civil War, when the constitutionality of a federal draft was hotly contested and never firmly resolved. ${ }^{10}$

Until World War I, a national draft was at least constitutionally suspect, but for Hughes its readily apparent military necessity-he had watched the European armies rely on it for several years - made its constitutionality an easy matter: "There is no limitation upon the authority of Congress to create an army and it is for the president as Commanderin-Chief to direct the campaigns of that army wherever he may think they should be carried on." For Hughes, the needs of modern warfare had displaced early-American faith in state militias as safeguards of republican government.

As it happened, Hughes's argument was vindicated the next year by the Supreme Court in a set of challenges grouped together as the Selective Draft Law Cases. ${ }^{11}$ Drawing on the widespread international practice of conscription, the Court, in a unanimous 


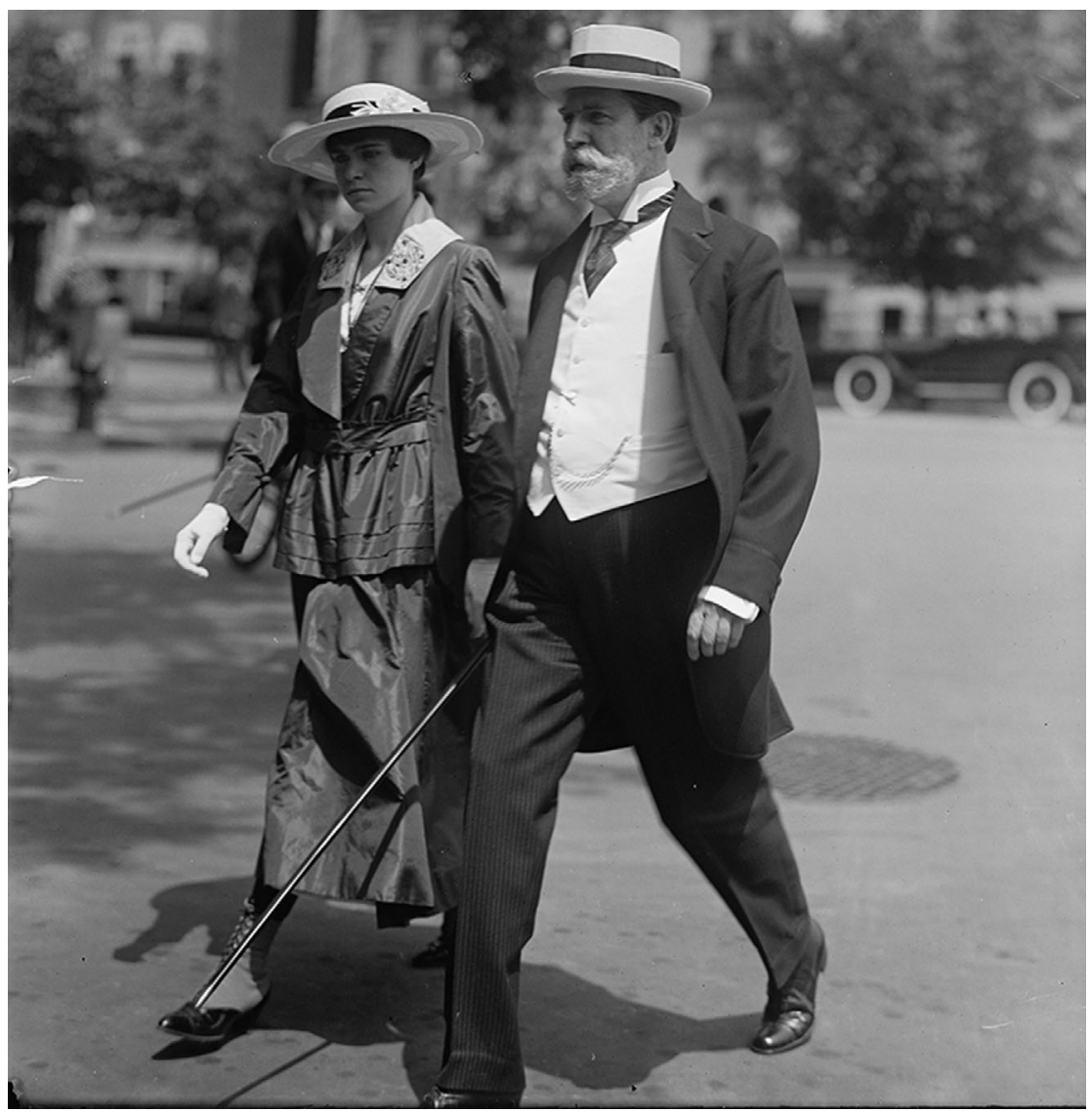

Charles Evans Hughes issued the phrase "The power to wage war is the power to wage war successfully" in an address he delivered as a private citizen at an American Bar Association conference on September 5, 1917, in Saratoga Springs, New York. He is pictured above walking with his daughter, Katherine.

opinion in those cases, held that the Militia Clauses were not a limitation on Congress's power to institute a national draft-at least not in the context of twentieth-century warfare.

Moving from the question of the draft to economic regulation, Hughes defended on war powers grounds vast new federal authority, as well as congressional delegation of that authority to the executive branch. In the words of historian and political scientist Clinton Rossiter, the wartime economic power granted by Congress was "infinitely more ... than had ever been given to an American president. In absolute terms, it far exceeded Lincoln's, for it extended to a control of the nation's economic life that would have caused a revolution in 1863." 12

In the months prior to Hughes's war powers speech, Congress had passed several far-reaching laws committing to President Wilson vast authority. Among the most famous was the Food and Fuel Control Act (also known as the Lever Act), which gave the President broad powers "to make such regulations and to issue such orders as are essential" to ensure adequate and equitable supply and distribution of those critical resources. ${ }^{13}$ This went against peacetime limitations on congressional power. It went against peacetime limits on congressional delegation of policy discretion. And it went 


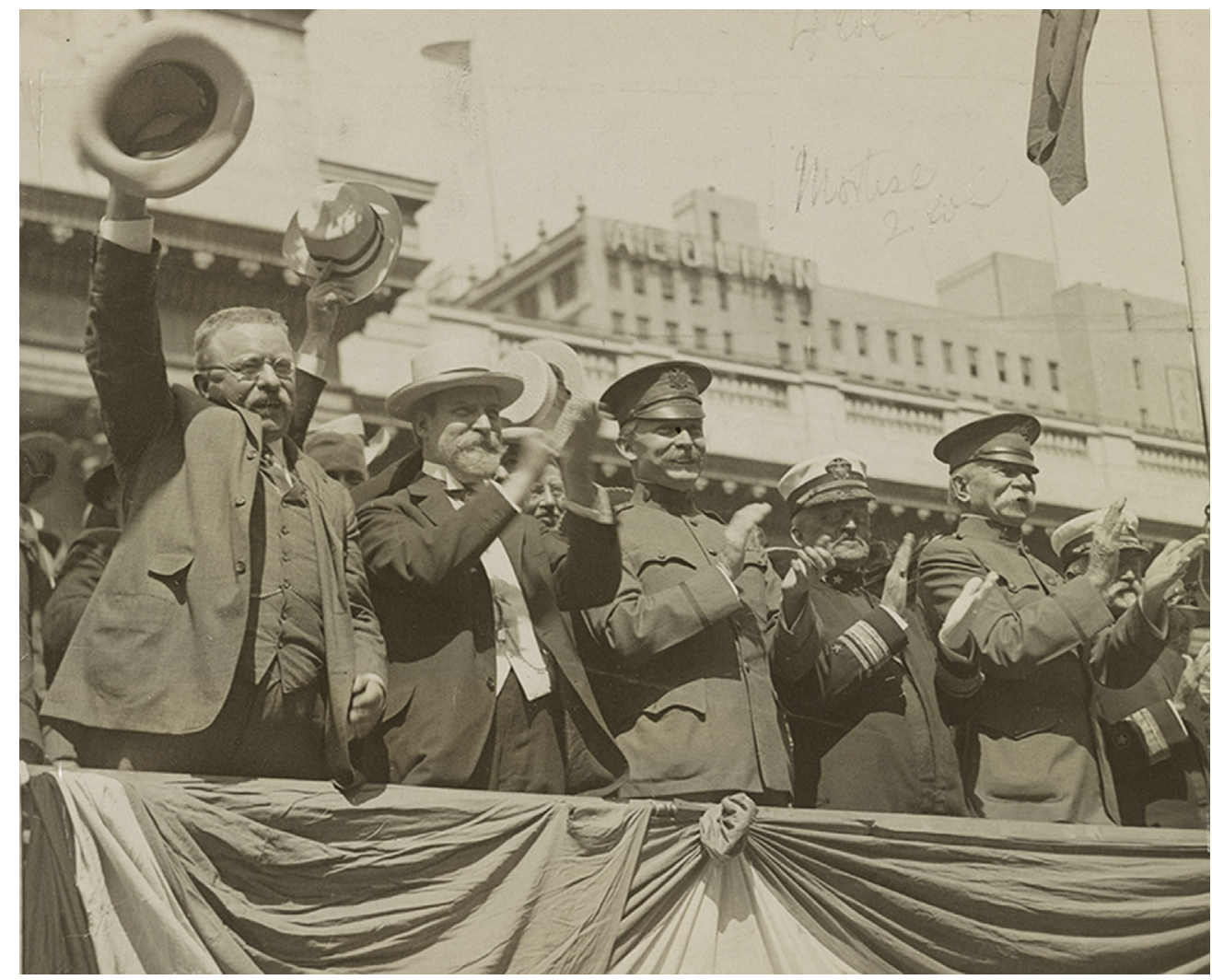

This photo shows Hughes (second from left) on the day before his war powers speech, standing alongside former President Theodore Roosevelt (left), in front of the New York Public Library watching 7,000 recently drafted soldiers march up Fifth Avenue. Many of those on parade likely had only weeks earlier received rejection letters to their draft appeals bearing Hughes's signature.

against peacetime understandings of Fifth and Fourteenth Amendment rights protecting so-called "private" economic activities.

Hughes argued that those peacetime limitations on Congress's powers must give way to wartime needs. Congress, he argued, "is confided the power to enact whatever legislation is necessary to prosecute the war with vigor and success." In these ways, Hughes's flexible and adaptive interpretation of the war power addressed the major problem he saw in September 1917, namely, how to mobilize the entire national industrial economy for modern, expeditionary war.

Again, in the end, the Supreme Court validated Hughes's views on wartime economic regulation and administration. Despite plenty of challenges and opportunities for judicial repudiation, no significant wartime economic regulation was struck down as beyond Congress's powers, as an unconstitutional delegation, or as violating constitutional economic or contractual rights.

This was, as Hughes would say, the Constitution marching in step with changes in warfare.

\section{The Problem of War Termination}

In addressing one constitutional problem, however, Hughes walked into another one that echoes today. For him, the elasticity of the power to wage war successfully was justified on two confident assumptions: that clear lines exist between wartime and peacetime, and that following successful war, there would be a reversion to 
constitutional normality. War-waging power would be only temporary. But what if it were not so temporary?

On November 11, 1918, the Allies and Germany signed the Armistice that ended the remaining fighting on the Western Front. Often an armistice is only a pause, or a ceasefire pending further negotiations, but this was a much more dramatic and decisive event. Two days earlier, German Kaiser Wilhelm II had abdicated. Under the Armistice terms, Germany had to withdraw its troops and hand over the bulk of its navy. President Wilson declared that day to Congress, "The war thus comes to an end, for, having accepted these terms of armistice, it will be impossible for the German command to renew it."14

The ultimate mission was not yet accomplished in November 1918, however. Although Germany had been subdued militarily at that point, President Wilson had taken the country to war with a boldly ambitious set of international security and diplomatic aims. He said we were making the world safe for democracy. Wilson viewed as essential to American security the replacing of traditional European balance-of-power politics with a new system of diplomatic rules, ideals, and collective responses to threats - and he had requested a war declaration from Congress on those terms. This ambitious, global agenda greatly complicated the task of determining when some baseline level of security was achieved and, therefore, when the expansive war powers of Congress and the President were required to retract back to peacetime form.

Put another way, if "the power to wage war is the power to wage war successfully," should those war powers have come to an end on November 11, 1918? Is the war successfully waged when the fighting stops on the battlefield? Or when the goals are achieved? Or something else? The U.S. government's position was that, although military victory was achieved in November 1918, as a legal matter war powers continued to operate.
At this point, the story of Hughes and war powers takes a major twist. For the next couple of years, Hughes repeatedly spoke out, wrote - and litigated - against the government for war powers overreach.

Hughes's statements after the November 1918 Armistice show anxiety about constitutional adjustment, not the confidence of his 1917 speech. In a Columbia University lecture just weeks after the Armistice, he remarked that the "astounding spectacle of centralized control ... has been the manifestation of the Republic in arms, fighting as a unit, with powers essential to selfpreservation, which the Constitution not only did not deny but itself conferred." 15 He went on to warn, however, that wartime conditions could be used pretextually to advance political and legal agendas, and he expected courts to play a checking role to ensure that the return to peace brought also a dismantling of the wartime administrative apparatus. "What will it profit the Republic if it gains the whole world and loses its own soul?" he asked in a 1919 New York Bar Association address. ${ }^{16}$ Once modern war powers were turned on, Hughes worried that the government would resist turning them off.

In a fascinating 1919 case, Commercial Cable Co. v. Burleson, ${ }^{17}$ Hughes unsuccessfully litigated this issue of when World War I ended as a legal matter. The specific dispute went as follows. Pursuant to a broad delegation of power over telecommunications systems, the federal government seized control of the undersea cables operated by private American companies. This would not have been very legally controversial, especially under Hughes's theories of expansive and flexible war powers, except for an important wrinkle: The government's seizure of the cables did not occur until about a week after the Armistice. Combat operations in Europe had halted. Hughes, who was in 1919 litigating cases at an incredible pace, regarded the seizures as "wholly unwarranted 


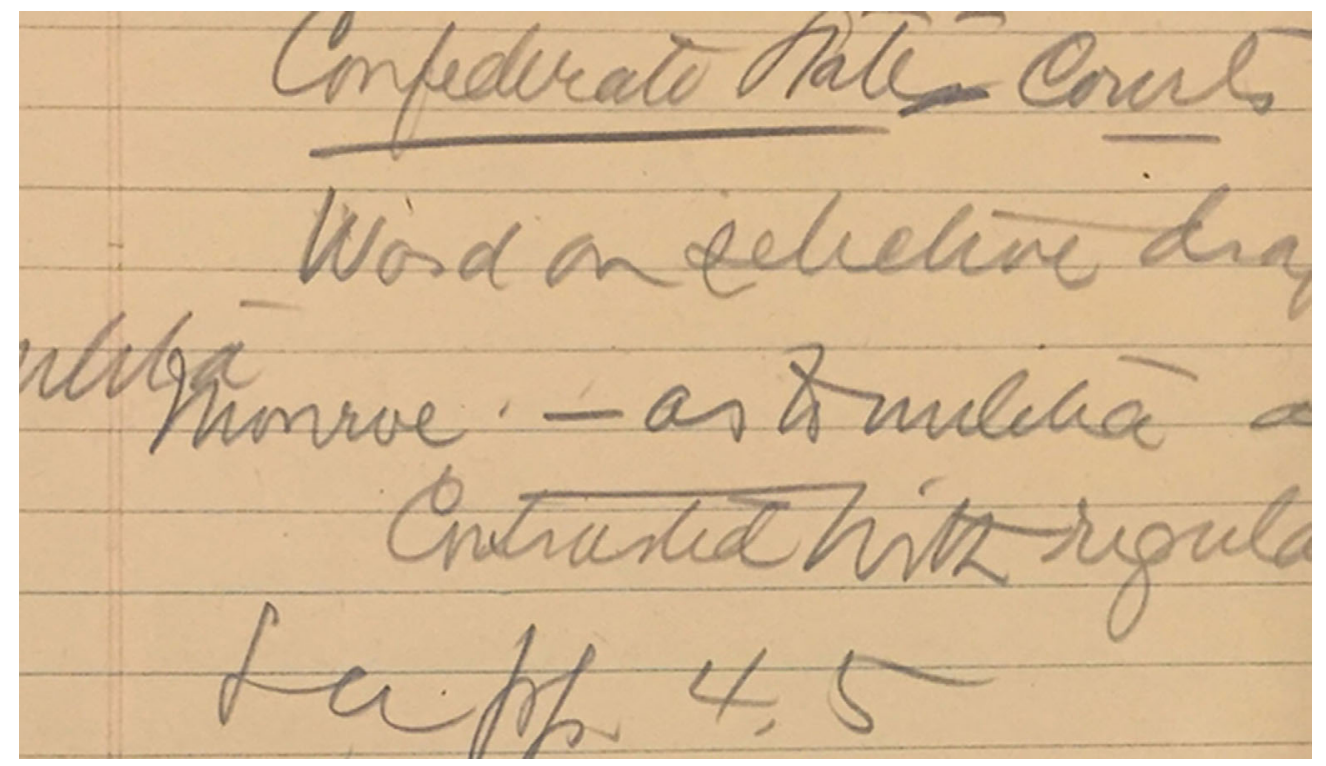

Hughes sketched out the rough outline of his argument by hand. His research notes for the speech are in his personal papers at the Columbia University manuscript and rare book library.

and arbitrary," and so he represented one of the cable companies. ${ }^{18}$

A notable aspect of this case is that it featured a dramatic courtroom debate in the Southern District of New York between Hughes and Judge Learned Hand-two of the greatest legal minds of the time-over how to measure the end of war. Was it based on readily observable military conditions, or did it depend on a political assessment that war aims had been achieved? Thanks to an extensive New York Times report of the courtroom arguments, we have a good record of their exchange across the bench. ${ }^{19}$

The main crux of Hughes's argument was that the cable seizure exceeded statutory authority, which was tied to the existence of an ongoing war and a threat to national security or defense, but there was also a constitutional dimension: He argued that in light of present circumstances, the broad delegation of power was illegitimate. Hughes argued that the war was, in a practical sense, over, and therefore the government's expansive, wartime regulatory authorities had expired.

Judge Hand pressed Hughes hard on this point in court: "[T]he security or defense of the nation depends, does it not, upon the objects for which the war was fought, and until those objects have been ascertained authoritatively by a peace, it cannot be said that the security and defense is established....Is that not so?"

\section{Hughes responded:}

I think that what may be achieved, in the sense of the final results of the war, will probably not be determined during our lifetime. ... It was not a danger in the sense of a nebulous regard for possible policies, which could not be vindicated and carried through by force, that Congress had in mind. It was an actual state of applied force that we were looking to in arming the President with these extraordinary powers....

Hughes pushed further in saying that this was not just any armistice: He pointed out that the President himself had told Congress that the enemy had been reduced to a state of helplessness. The President had stated that the enemy could not have resumed the war. 
The president acknowledged that the war no longer posed a direct security threat to the people of the United States.

Judge Hand then turned Hughes's axiom back on him, essentially saying that if the power to wage war is the power to wage war successfully, then success should be gauged not just by the absence of immediate danger but by reference to the ultimate war aimsand the President and Congress should determine what those aims are. "[S] urely all means necessary to the achievement of that final end are necessary to the security and defense of the nation."

Hughes lost that case-Judge Hand interpreted the President's cable seizure power as unreviewable, ${ }^{20}$ and Hughes's appeal to the Supreme Court was mooted when the government relinquished control over the cables - but Hughes continued to press this war termination issue. In fact, in a 1920 speech, he ramped up his warnings, declaring that "we may well wonder in view of the precedents now established whether constitutional government as heretofore maintained in this republic could survive another great war even victoriously waged." 21 Around that time, Hughes litigated other claims that the security threat had sufficiently diminished so that the government's war power should cease, too, but those cases were all resolved on other grounds.

The story of Hughes and his war powers axiom then takes another turn, however. Just a few years later, Hughes curiously seems to have backed off his earlier concerns, taking him back around to his core 1917 position, as his worries about war termination and indefinite war powers were apparently allayed. In a series of 1927 Columbia University lectures, Hughes, without at all addressing the endof-war issue, re-emphasized his arguments that the power to wage war is the power to wage war successfully. ${ }^{22}$ As Chief Justice, in a 1934 opinion about a state mortgage regulation during the Great Depression, he doubled down on this war powers axiom by using it now to help justify general emergency powers. ${ }^{23}$

Part of the answer to why Hughes returned to this position is probably the result of political process. Upon taking control of the White House in 1921, President Warren Harding had pledged the return to "normalcy." Hughes would serve as Harding's Secretary of State, and Hughes negotiated the formal peace treaty with Berlin soon after the President signed Congress's joint declaration finally ending World War I in July 1921. Another factor in Hughes's apparent return to comfort with vast war power probably has to do with the judiciary. Also in the early 1920s, the Supreme Court seemed to reserve at least some minimal role for courts in policing the durational boundaries of war powers. ${ }^{24}$ These precedents, especially when combined with the political shifts just mentioned, would likely have mitigated Hughes's concerns that war powers would be perpetuated indefinitely. Yet it remains somewhat of a mystery how Hughes reconciled his expansive theory of wartime legislative powers with the concern-so clearly illustrated in the cable seizure case - that they could and would be extended in time well beyond what he thought was justified.

\section{The Fighting Constitution a Century Later}

Studying Hughes's 1917 speech today, a little more than a century later, one is struck by both its timeless and its anachronistic features. The specific controversiesthe draft and economic regulation-are of a bygone era, but the central claim that our "fighting constitution" confers flexible powers to "wage war successfully" still holds.

Today's war powers controversies are rarely about the extent and limit of Congress's powers, as they were in 1917. They are mostly about the scope of the President's unilateral war powers. One reason for this shift in emphasis is the growth of presidential power, especially since the 


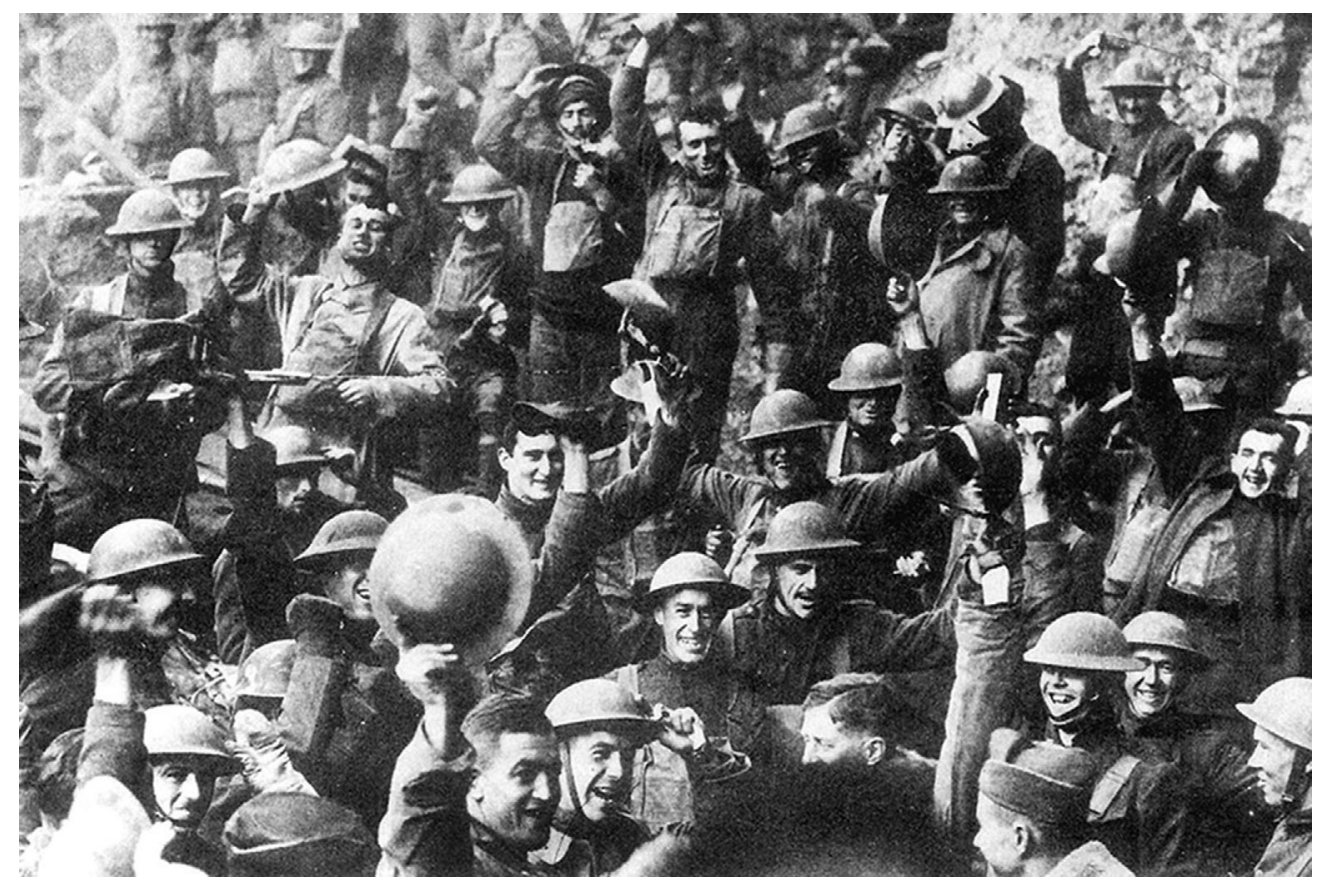

For Hughes, there was an assumption that following a successful war, there would be a reversion to constitutional normality. But the power to wage war turned out to not be as temporary as he envisioned. Above, men of the U.S. 64th Regiment, 7th Infantry Division, celebrated the news of the Armistice on November 11, 1918.

early Cold War. But another reason, so apparent in reflecting on Hughes's speech, is that Congress's other powers - its nonwar powers - have expanded so dramatically since World War I. All of the domestic economic regulations justified during World War I as an exercise of constitutional war powers could, by the end of World War II, easily have been justified under a farbroadened reading of the commerce powereven in peacetime. Doctrines and the exercise of nonwar emergency legislative powers have expanded, too. Since World War I, Congress has enacted hundreds of emergency power provisions that the President may activate by proclaiming a national emergency, whether or not the country is in a state of war.

Looking back, then, World War I was probably the pivotal moment in American history when the differential between the federal government's war powers and its normal, peacetime powers reached its apex. Once warfare became "total" in the early twentieth century, legislative war powers became the basis for completely transforming a largely laissez faire system into a centrally administered statist one and for subordinating a state militia system to the federal government's army powers. War has continued to become more complex, but legislative war powers have not had to keep up in part because other constitutional powers now provide such vast authority. Reading Hughes's speech today is an important reminder that war no longer opens much otherwise locked-up legislative power.

I say "much," because it does open some powers. The wars against al-Qaeda and the "Islamic State" terrorist organization in recent decades have reopened the issue of the substantive scope of legislative war powers. In particular, they have raised questions (sometimes answered using citations to Hughes's 1917 axiom), such as the scope of wartime constitutional powers to detain enemy fighters or to try them in military 
commissions. ${ }^{25}$ On the one hand, these claimed powers seem exceptional because the war against sprawling transnational terrorist groups lacks the organizational, geographic, and temporal boundaries usually associated with modern warfare, although this story is a good reminder that struggling with temporal boundaries of warfare is not a new problem. On the other hand, powers such as detaining enemy fighters or trying them in military commissions are quite ordinary and limited. The context in which the government seeks to use these powers is extraordinary, but the measures themselves are traditional to military conflict, much more akin to the wartime powers that the constitutional framers envisioned than those Hughes defended during World War I.

Finally, the ongoing war with transnational terrorist groups has made Hughes's post-Armistice concerns about enduring war powers seem forewarning. One hears echoes of Hughes' cable-seizure-case arguments in today's arguments against indefinite wars with terrorist groups. The challenge of indefinite war against terrorist organizations is not simply one of attaining a successful military outcome. As with determining whether World War I had been "wage[d] successfully," it is also a matter of defining the terms of victory.

\section{ENDNOTES}

${ }^{1}$ For a more detailed version of this story, see Matthew C. Waxman, "The Power to Wage War Successfully," 117 Columbia L. Rev, p. 613 (2017).

${ }^{2}$ Charles E. Hughes, "War Powers Under the Constitution," Annual Report of the American Bar Association, vol. 40, 1917, p. 232. All further quotes or references to his 1917 speech are from the same source.

${ }^{3}$ David M. Kennedy, Over Here: The First World War and American Society (1980), 3-44.

${ }^{4}$ N.Y. Times, Sept. 6, 1917, 1.

${ }^{5}$ Charles E. Hughes, "War Powers Under the Constitution,” St. Louis Post-Dispatch, Sept. 9, 1917, pp. 1, 11.

${ }^{6}$ All quotes or references to Hughes's notes come from Charles Evans Hughes Papers, 1914-1930, Columbia University Rare Book \& Manuscript Library, Box 56.
${ }^{7}$ Merlo J. Pusey, Charles Evans Hughes, vol. 1, 371 (1951); "Hughes Board Speeds Up; Decides 178 Cases in Day," N.Y. Tribune, Aug. 21, 1917, p. 6.

8 "City to Review Draft Army in March Today," N.Y. Tribune, Sept. 4, 1917, p.1.

${ }^{9}$ U.S. Constitution, Article 1, Section 8.

10 James G. Randall, Constitutional Problems Under Lincoln (1926), 11-12.

11245 U.S. 366 (1918).

${ }^{12}$ Clinton Rossiter, Constitutional Dictatorship (1948), 241-42.

13 Pub. L. No. 65-41, §1, 40 Stat. 276, 276 (1917).

${ }^{14}$ President Woodrow Wilson to Joint Session of Congress, November 11, 1918.

15 This lecture was published several months later as Charles Evans Hughes, "Our After-War Dangers: In Saving the World Have We Lost Our Republic?" 61 Forum p. 23 (1919).

${ }^{16}$ Charles E. Hughes, President, N.Y. State Bar Ass'n, "The Republic After the War," in Proceedings of the Forty-Second Annual Meeting of the N.Y. State Bar Association (Jan. 1919). Pp. 224, 233.

17255 F. 99 (S.D.N.Y.), rev'd as moot, 250 U.S. 360 (1919).

${ }^{18}$ David J. Danelski \& Joseph S. Tulchin eds., The Autobiographical Notes of Charles Evans Hughes (1973), 191.

19 "Hughes Assails Seizure of Cables," N.Y. Times (Dec. $28,1918)$, p. 5. All quotations from this hearing come from this source.

${ }^{20}$ Commercial Cable Co. v. Burleson, 255 F. 99, 103-104 (S.D.N.Y. 1919).

${ }^{21}$ Charles E. Hughes, Some Observations on Legal Education and Democratic Progress 4 (June 21, 1920).

${ }^{22}$ Charles Evans Hughes, The Supreme Court of the United States (1928), 102-103.

${ }^{23}$ Home Building \& Loan Ass'n v. Blaisdell, 290 U.S. 398, 426 (1934).

${ }^{24}$ Daniel J. Hulsebosch, "The New Deal Court: Emergence of a New Reason," 90 Colum. L. Rev., pp. 1973, 2006 (1990).

${ }^{25}$ Memorandum from John C. Yoo, Deputy Assistant Attorney Gen. \& Robert J. Delahunty, Special Counsel, Office of Legal Counsel, to Alberto R. Gonzales, Counsel to the President \& William J. Haynes, General Counsel of the Dep't of Def., Authority for Use of Military Force to Combat Terrorist Activities Within the United States 15 (Oct. 23, 2001); Legality of the Use of Military Commissions to Try Terrorists, 25 Op. O.L.C. 238, 245 (2001); Respondents' Memorandum Regarding the Government's Detention Authority Relative to Detainees Held at Guantanamo Bay at 6 n.2, In re Guantanamo Bay Detainee Litigation, Misc. No. 08-442 (TFH) (D.D.C. Mar. 13, 2009). 